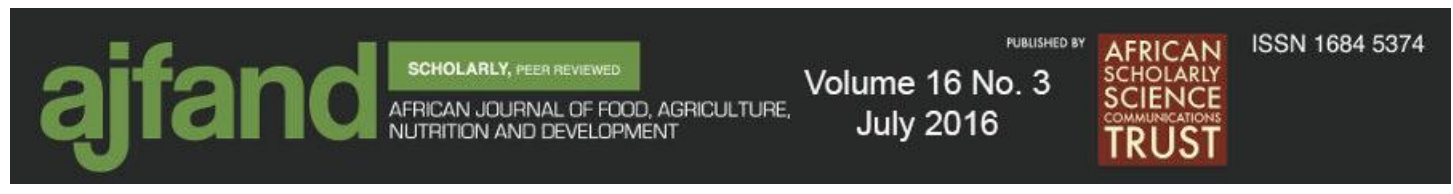

10.18697/ajfand.75.ILRI04

\title{
PREVALENCE OF AFLATOXIN IN FEEDS AND COW MILK FROM FIVE COUNTIES IN KENYA
}

Senerwa DM", 2*, Sirma AJ', ${ }^{1,}$, Mtimet $\mathrm{N}^{1}$, Kang'ethe EK ${ }^{2}$, Grace $D^{1}$ and JF Lindahl ${ }^{1,3}$

*Corresponding author email: dsenerwa@gmail.com

IInternational Livestock Research Institute, P.O. Box 30709-00100, Nairobi, Kenya ${ }_{2}$ Department of Public Health, Pharmacology and Toxicology, University of Nairobi, P.O. Box 29053-00625, Nairobi, Kenya

3Department of Clinical Sciences, Swedish University of Agricultural Sciences, P.O. Box 7054, SE-750 07 Uppsala, Sweden 


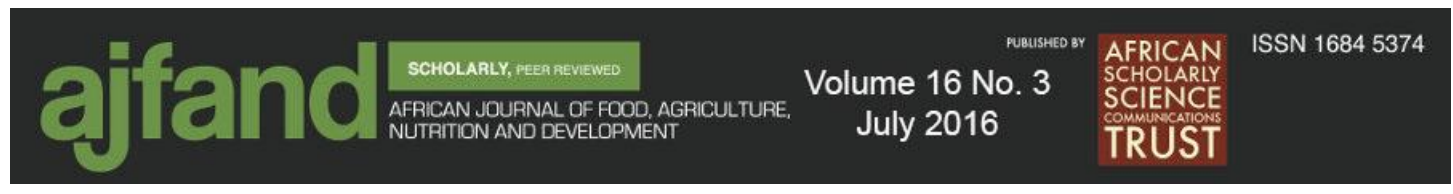

\begin{abstract}
Mycotoxin-producing fungi contaminate food and feeds before, during and after harvest. Aflatoxins are important mycotoxins and aflatoxin B1 (AFB1) is a class 1 human carcinogen (definitely carcinogenic). Aflatoxin M1 (AFM1) is a class 2B (possible) human carcinogen. Aflatoxin B1 in feeds can decrease milk production, reduce fertility and increase susceptibility to infections. A cross-sectional study of aflatoxin contamination of milk and dairy feeds was carried out in five counties in Kenya representing different agro-ecological zones: Kwale, Isiolo, Tharaka-Nithi, Kisii and Bungoma. Dairy feed concentrates and cattle milk were collected twice (dry season and rainy season) from 285 dairy farmers in the five counties and analysed for AFB1 and AFM1, using competitive enzyme-linked immunosorbent assay (ELISA). In the five counties, the proportion of farmers who fed cattle with dairy concentrates varied from zero to $68 \%$. The dairy feed concentrates from farmers had AFB1 levels ranging from less than one part per billion (ppb) to $9661 \mathrm{ppb}$ and the positive samples ranged from 47.8 to $90.3 \%$. The percentages of dairy feeds from farmers with AFB1 above the World Health Organization/Food and Agriculture Organization of the United Nations (WHO/FAO) limit of $5 \mathrm{ppb}$ varied from $33.3 \%$ to $87.5 \%$ while $83.3 \%$ to $100 \%$ of the feeds from retailers and $28.6 \%$ to $100 \%$ of the feeds from manufacturers exceeded the WHO/FAO limit. Aflatoxin M1 prevalence in milk was lowest in Kwale (13.6\%) and highest in Tharaka-Nithi (65.1\%). The proportion of milk samples with AFM1 above the WHO/FAO standard of 50 parts per trillion (ppt) varied from $3.4 \%$ (Kwale) to $26.2 \%$ (Tharaka-Nithi); the highest was 6999ppt. This study shows that aflatoxin contamination is common in dairy feeds and in milk and concentrations may be high. This may contribute to ill health effects in both humans and animals and, therefore, there is need for better understanding of the impacts of aflatoxins in the feed-dairy value chain and appropriate interventions to control aflatoxin contamination in animal feeds.
\end{abstract}

Key words: aflatoxins, feeds, dairy cattle, milk, Kenya, dairy value chain, mycotoxins, food safety 


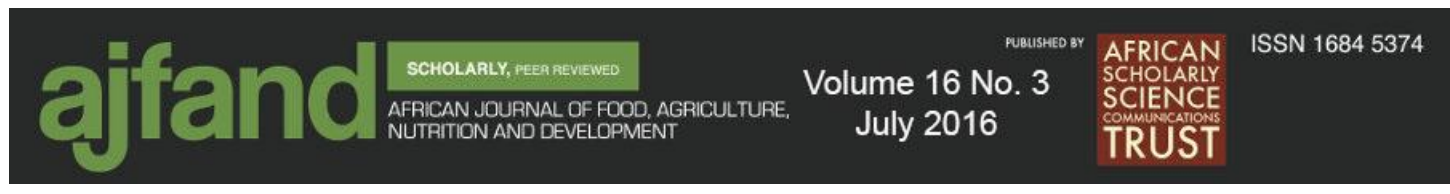

\section{INTRODUCTION}

Kenya's dairy industry is a major source of livelihood for farmers, milk processors, milk traders, feed manufacturers and feed retailers. The industry contributes $14 \%$ of the agricultural gross domestic product (GDP) and 3.5\% of the total GDP [1]. Milk production in Kenya is mainly from cattle; camels and goats contribute to a lesser extent [2]. Dairy cattle breeds produce $70 \%$ of milk. The number of dairy cattle was estimated at 3.6 million in 2007 by the Government of Kenya [2]. In 2007, the former Rift Valley Province was estimated to have $53 \%$ of the dairy cattle population, while former Central had 24\%, Eastern had 8\%, Nyanza had 6\%, Western had 5\%, Coast had 3\% and Nairobi $1 \%[2]$.

The Kenya dairy production system consists of a mix of small-scale dairy farming and large-scale dairy production, but small-scale dairy farming predominates producing about $80 \%$ of the milk in the country [3]. There is a higher concentration of smallholder dairy farms in peri-urban areas where there is easy access to marketing channels for highpriced unpasteurized and pasteurized milk. Large dairy farms are owned by public institutions and companies as well as individuals [4]. Smallholder dairy production usually involves stall-feeding of fodder and grass (zero-grazing) supplemented with homemade or purchased concentrate feed [5]. Large-scale dairy production in Kenya mainly utilises pastures with little concentrate feed. Kenya has a high milk consumption: one estimate suggests consumption of 145 litres per capita per year, which is over three times the consumption in other East African countries [6]. However, the average milk production per dairy cow per year is low, $2920 \mathrm{~kg}$ in Kenya, compared to $4590 \mathrm{~kg}$ in South Africa and 10,096 kg in the United States of America [7-9].

Food safety is important in both developed and developing countries. In Kenya, milk is liable to contamination with hazards including aflatoxins. Aflatoxins are mycotoxins produced mainly by Aspergillus flavus and A. parasiticus moulds. The major aflatoxins are B1, B2, G1 and G2 [10]. Aflatoxin M1 (AFM1) and M2, the hydroxylated products of B1 and B2, are found in milk and milk products. Aflatoxin B1 (AFB1) is considered a class 1 carcinogen and can cause acute and chronic illness in people and animals [10]. Aflatoxin M1 is a class 2B (possible) human carcinogen.

Maize, the staple food in Kenya, is often contaminated with high concentrations of aflatoxins and this has caused acute fatal aflatoxicosis in humans [11-17]. High concentrations of aflatoxins and trichothecenes in feed can also cause high mortality in cattle [18], while chronic aflatoxin poisoning in dairy cattle leads to a decrease in feed conversion efficiency, milk production and reproductive efficiency $[19,20]$. There have been many studies on aflatoxins in crop products in Kenya [11-17, 21, 22], but less attention has been paid to aflatoxins in dairy products. In Kenya, studies on the prevalence of AFB1 in dairy feeds and AFM1 in milk were mainly conducted in urban and peri-urban areas [23-25]. The present study tries to fill this gap by assessing aflatoxin contamination and prevalence in dairy feeds and milk in all milk-producing agroecological zones (AEZs) in Kenya. 


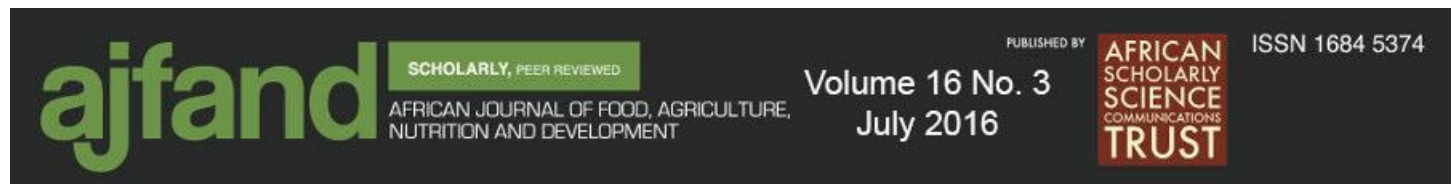

\section{METHODS}

\section{Study site selection}

A map showing AEZs of Kenya [26] was used to select the study sites. The counties in each AEZ were listed and one study site each was randomly selected from the sub-humid, humid and semi-arid zones; two study sites were selected from the temperate zone, as this zone is favourable for dairy keeping. The arid zone was not sampled as it is not favourable for dairy breeds. The randomly selected counties were Kisii and Bungoma (temperate), Tharaka-Nithi (humid), Kwale (sub-humid) and Isiolo (semi-arid) (Figure 1). One sub-location was randomly selected from each county.

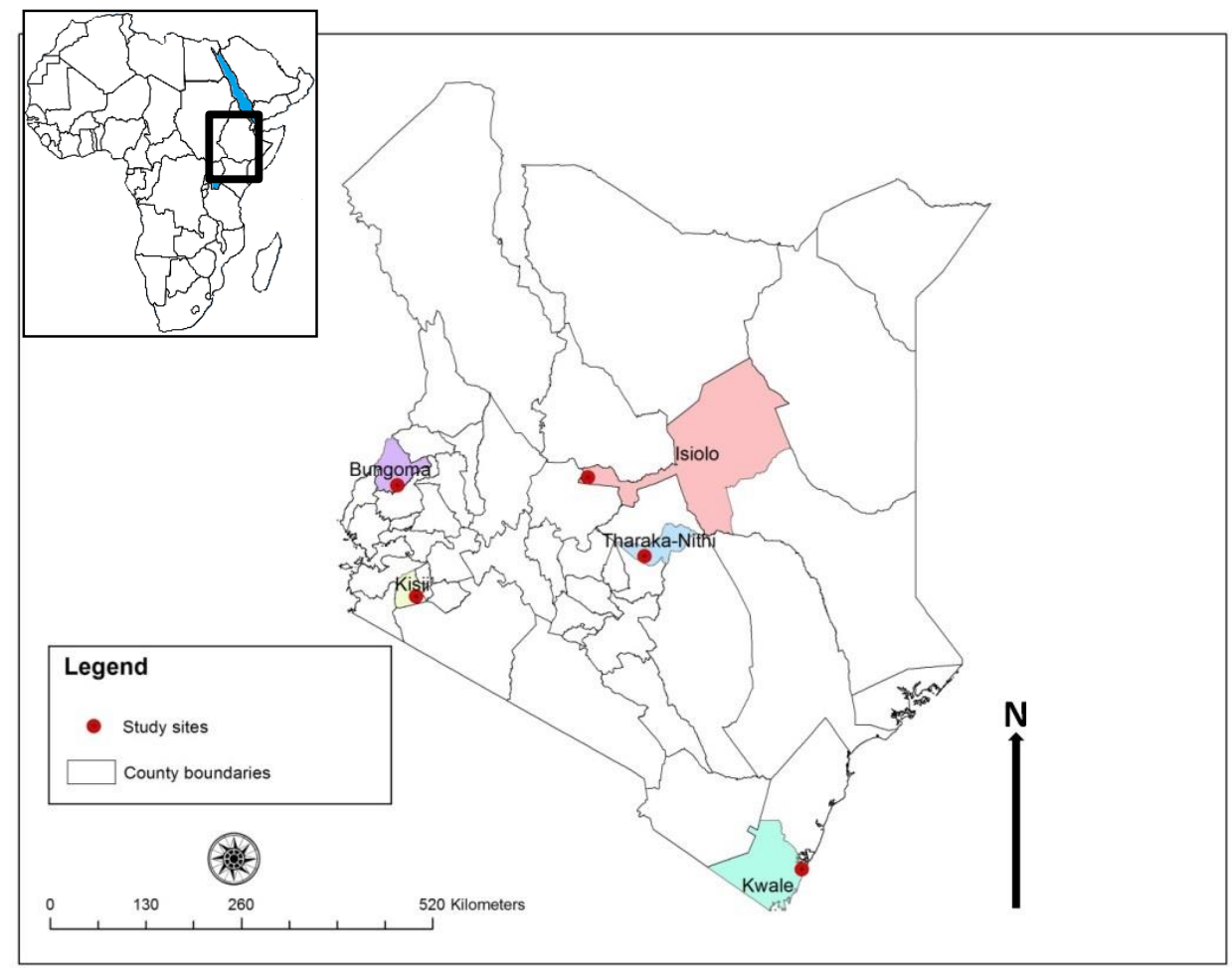

Figure 1: Map of Kenya showing the study sites

\section{Sampling}

Multistage cluster sampling was used, with sub-locations, then villages and then dairy farmers randomly selected using computer-generated random numbers [27]. To do this, sampling frames were constructed of sub-locations, villages within the selected sublocations and then farmers with at least one milking cow within the villages. Eight villages were selected from each sampling sub-location, and in each village, eight eligible farmers were randomly selected. Sampling was planned to coincide with the dry (February and March 2014) and rainy (July and October 2014) seasons. Aflatoxin production is higher in feeds stored in damp conditions and this study sought to investigate the effect of season on aflatoxin outcome of the feeds and milk. 


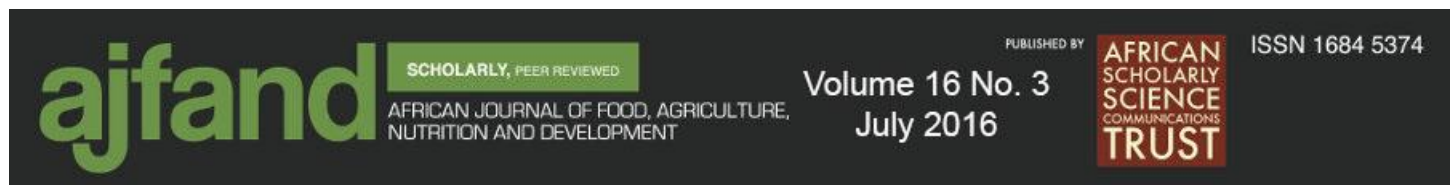

To get representative samples, bulk household milk (300 ml) was taken and feed (500 g) scooped at three levels from a bag (top, middle and bottom). To sample the feed, a scoop sterilised in sodium hypochlorite was used. The farmers gave the location of feed retailers from where they purchased feeds. All feed retailers in the local market were sampled. In addition, feed samples were obtained from the manufacturers who supplied the retailers, using the sampling method described earlier. One sample of each type of dairy feed available was taken from the farmer, feed retailer and feed manufacturer. In Isiolo County, there were no feed retailers and none of the farmers fed their cattle on concentrates. Feed samples were transported in boxes and kept in a cold room at $4^{\circ} \mathrm{C}$. Milk samples were frozen at $-20^{\circ} \mathrm{C}$. Analysis was carried out at the Department of Public Health, Pharmacology and Toxicology, University of Nairobi and the Biosciences Eastern and Central Africa-International Livestock Research Institute (BecA-ILRI) Hub. Ethical approval for the study was acquired from the International Livestock Research Institute (approval number ILRI-IREC2013-09). In addition, a short questionnaire was completed for each farm.

\section{Aflatoxin B1 analysis in feed}

Aflatoxin B1 analysis of the feeds was done using a low matrix competitive AFB1 enzyme-linked immunosorbent assay (ELISA) kit for cereals and grains (Helica Biosystems, Inc., Santa Ana, CA 92704, USA, Catalog No. 981BAFL01LM-96 Low Matrix), according to the manufacturer's instructions. Calf pellets with a large particle size were ground using a Romer grinder (Romer Series II Mill from Romer Labs Inc., 1301 Stylemaster Drive Union, MO 63084, USA). Samples with AFB1 values above the highest standard concentration were further diluted and the assay conducted again until the AFB1 value quantified fell between the lowest and the highest aflatoxin values in the standards. The limit of detection for AFB1 was one part per billion.

\section{Aflatoxin M1 analysis}

Quantification of AFM1 was done using a commercial Helica ${ }^{\circledR}$ AFM1 ELISA quantitative kit (Helica Biosystems, Inc., Santa Ana, CA 92704, USA, Catalog No. 961AFLM01M-96) according to the manufacturer's instructions. Samples with AFM1 values above the highest standard concentration were further diluted and the assay conducted again until the AFM1 value quantified fell between the lowest and the highest aflatoxin values in the standards. The limit of detection of AFM1 was two parts per trillion (ppt).

\section{Data analysis}

Data were entered into Microsoft Excel 2010 and exported to Stata Version 13. The data were analysed using descriptive statistics. The AFB1 and AFM1 concentrations in feeds and milk did not follow the normal distribution. In calculation of geometric means, values lower than the limit of detection of AFB1 and AFM1 were replaced by half the value of the limit of detection for the respective kits to avoid biasing the results. Two-sample Wilcoxon rank-sum (Mann-Whitney) test was used for analysis of variance of median aflatoxin levels among counties and AEZs. Wilcoxon sign-rank test was used to evaluate difference between households that were sampled during both seasons. 


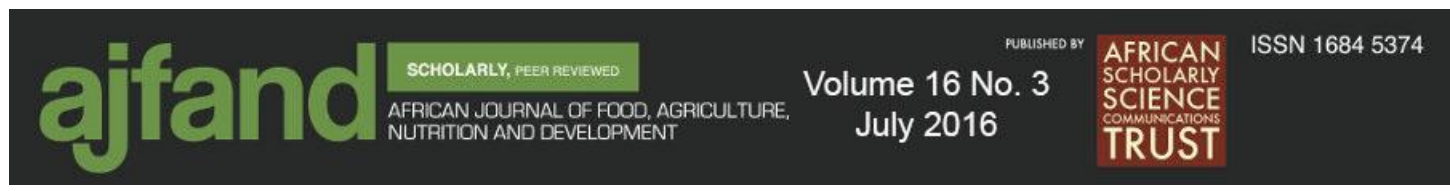

\section{RESULTS}

\section{Cattle breeds kept and milk production}

A total of 285 households were surveyed. Cattle breeds kept included Friesian, Ayrshire, Guernsey and Jersey (dairy breeds), cross breeds and local breeds (Table 1). Farmers in Kisii and Tharaka-Nithi counties had a higher proportion of dairy breeds and a larger proportion of households fed dairy concentrates to cattle. Daily milk production per cow varied from 0.15 litres for local breed cattle in a farm in Isiolo to 29 litres for dairy cattle in a farm in Kwale and mean daily milk production per cow was highest in Kisii (Table 2). All calves in Isiolo and Kwale counties suckled from their dams. Tharaka-Nithi had the highest proportion of farmers feeding the calves on milk (20/64), followed by Kisii (10/64) and Bungoma (3/64). The amount of milk fed to calves varied from 0.5 to seven litres per calf per day.

\section{Samples collected}

A total of 285 households provided samples: 37 in Kwale, 56 in Isiolo, 64 in TharakaNithi, 64 in Kisii and 64 in Bungoma. A total of 512 milk samples were obtained from the households. Two hundred and seventy seven feed samples were collected from households $(n=144)$, feed retailers $(n=31)$ and feed manufacturers $(n=102)$. Feed manufacturers were from the counties of Mombasa (supplies Kwale County), Meru (supplies Tharaka-Nithi County), Bungoma (supplies Bungoma County) and Nakuru (supplies Kisii and Bungoma counties). The dairy feeds consisted of dairy meal, pollard, maize, maize germ, maize bran, rice germ, rice bran, wheat pollard, wheat bran, young stock, calf meal, calf pellet, sorghum, cotton seed, sunflower and pyrethrum mix and home-made concentrates.

\section{Aflatoxin B1 in feeds from feed manufacturers, feed retailers and farmers}

Geometric means of AFB1 in feeds from feed manufacturers, feed retailers and farmers were 9.8 parts per billion (ppb), $25.6 \mathrm{ppb}$ and $13.7 \mathrm{ppb}$, respectively (Table 3, 4 and 5). All feeds from feed manufacturers from Meru County had AFB1 levels above the World Health Organization/Food and Agriculture Organization of the United Nations (WHO/FAO) limit of $5 \mathrm{ppb}$ (Table 3). Aflatoxin B1 (AFB1) concentration in farmers' feeds (geometric means) was highest in Tharaka-Nithi (Table 5). Home produced dairy feeds had lower AFB1 geometric means $(0.4 \mathrm{ppb}$ in the dry season, $\mathrm{n}=18 ; 18.9 \mathrm{ppb}$ in the rainy season, $n=4)$ than purchased feeds $(7.0 \mathrm{ppb}$ in the dry season, $\mathrm{n}=41 ; 25.3 \mathrm{ppb}$ in the rainy season, $n=20$ ). In Tharaka-Nithi County (humid AEZ), the rainy season AFB1 concentration in farmers' feeds was higher than that of the dry season as shown by the Wilcoxon rank-sum test at $95 \%$ level of confidence (Table 6). Prevalence of AFB1 in farmers' feeds is shown in Figure 2. In the dry season, Bungoma County had the highest AFB1 levels with $25 \%$ of the samples having concentrations above $55 \mathrm{ppb}$, followed by Kisii County with $25 \%$ of the samples above $40 \mathrm{ppb}$. In the rainy season, Tharaka-Nithi County had many feed samples with high AFB1 concentration, up to 9661 ppb. In Isiolo County, there was rain failure in July 2014, so no feed samples were available as farmers did not use dairy feed. 

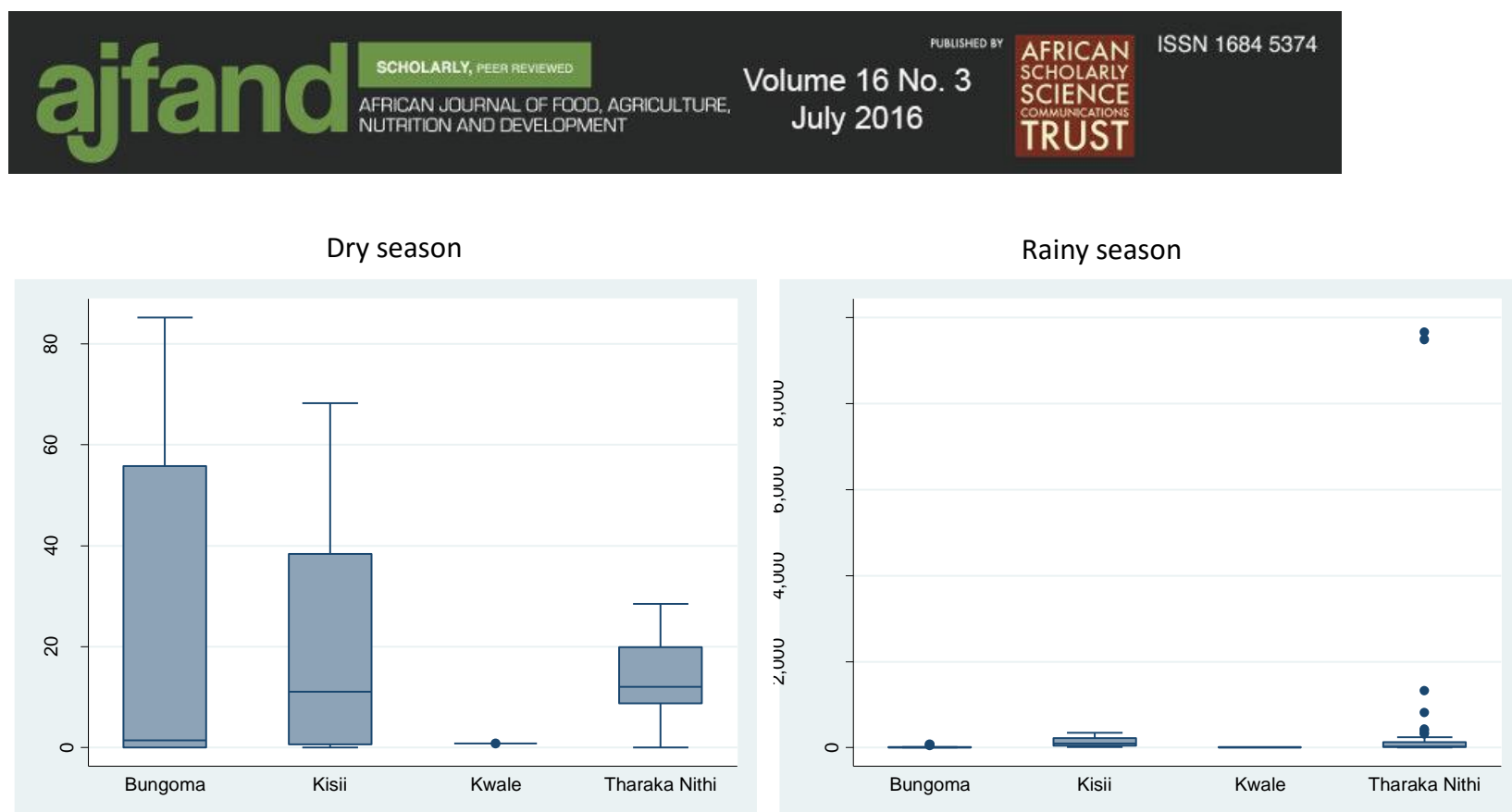

Figure 2: Levels of aflatoxin B1 (AFB1) in farmers' feeds in the dry season and rainy season

\section{Aflatoxin M1 in milk}

In total, 512 samples from 282 farmers were analysed and $39.7 \%$ of these had levels above the limit of detection, and $10.4 \%$ exceeded 50 ppt. Tharaka-Nithi County (humid AEZ) had the highest proportion of milk samples (26.2\%) with AFM1 concentrations above the WHO/FAO limit of $50 \mathrm{ppt}$ (Table 7). Milk samples from Isiolo County had higher AFM1 levels in the July dry season than the February dry season $(\mathrm{p}=0.02$, Table 8). The Wilcoxon sign-rank test for Bungoma County showed the AFM1 milk concentration was higher in the dry season than the rainy season $(\mathrm{p}<0.001$, Table 8$)$. The distribution of milk samples with AFM1 is shown in Figure 3. In the dry season, Kwale County had the highest median (>200 ppt AFM1 in milk), followed by Kisii County with an AFM1 median above 100 ppt. During the rainy season, Tharaka-Nithi and Kisii counties had milk AFM1 values above 900 ppt and 400 ppt, respectively.
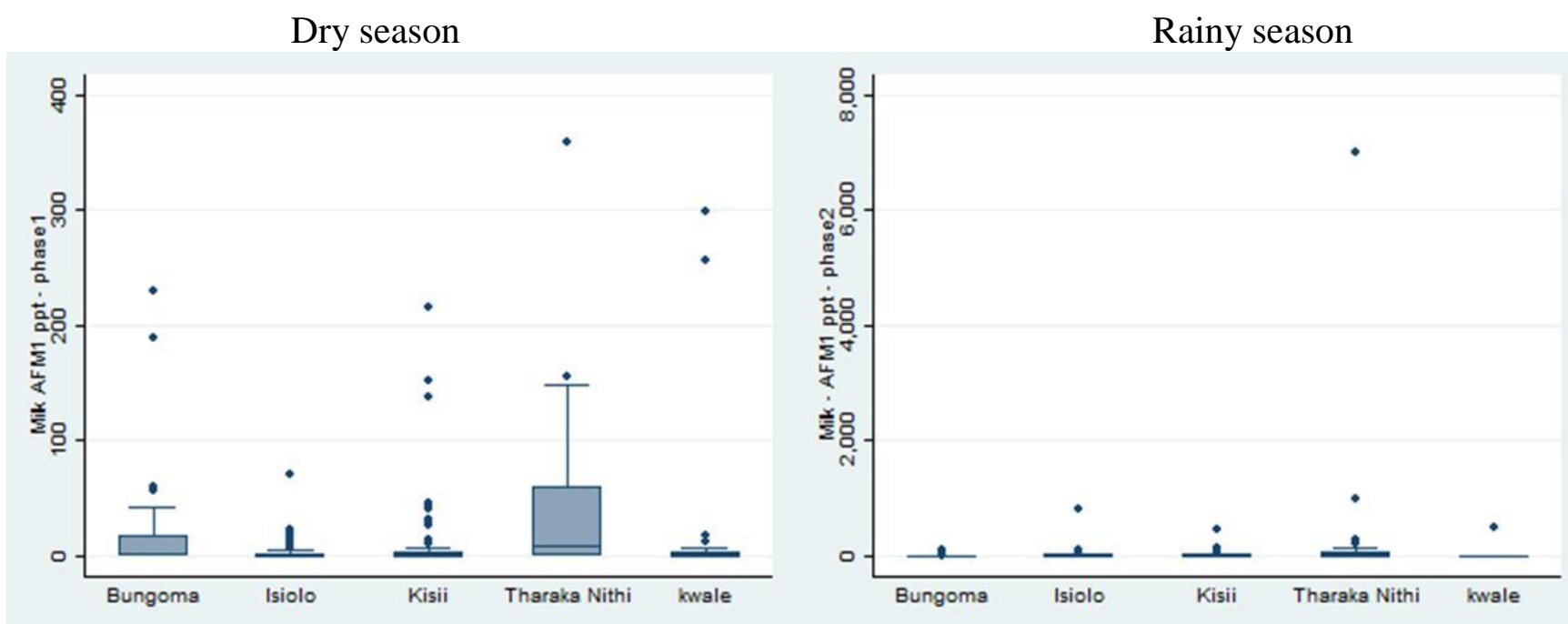

Figure 3: Levels of aflatoxin M1 (AFM1) in cow milk in dry and rainy seasons 


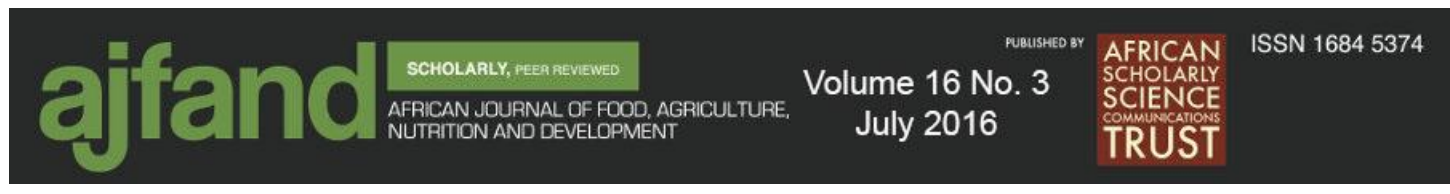

\section{DISCUSSION}

This study describes levels of aflatoxins present in cattle feed and cattle milk, assessed in one year in Kenya. The high prevalence and concentration of AFB1 in dairy feeds and AFM1 in cattle milk from rural villages and urban centres reported in this study are comparable to earlier reports in Kenya from urban and peri-urban areas [23, 24] but higher than those reported from Ethiopia [28]. The geometric mean AFB1 in feed from farmers is lower than that in feed from feed retailers, possibly due to lower initial aflatoxin contamination of home-made feeds or poor storage practices of the manufactured feeds along the dairy feed value chain. The higher AFB1 concentration in feed from feed retailers compared to that in feed from feed manufacturers suggests contamination or multiplication of Aspergillus fungi along the dairy feed chain. TharakaNithi and Kisii counties had a higher proportion of dairy breeds and a corresponding higher proportion of farmers who fed dairy concentrates to cattle. This led to higher proportions of milk from the two counties exceeding the 50 ppt AFM1 WHO/FAO limit.

Feed aflatoxin concentrations above $100 \mathrm{ppb}$ were recorded in Tharaka-Nithi County and this may be due to the presence of high-aflatoxin-producing Aspergillus strains in this region [29] and/or feed storage conditions that favour the multiplication of Aspergillus fungi. High AFB1 concentrations in dairy feeds have been shown to reduce milk production by up to $25 \%$ [19] and decrease in feed conversion efficiency and reproduction efficiency [20].

The low AFM1 concentrations in Bungoma during the rainy season may be due to availability of natural pastures and low use of dairy concentrates. Isiolo County was dry in July and dairy concentrates were not fed to the cattle. However, there was rain in the neighbouring counties of Laikipia and Meru. This may have raised the relative humidity of the environment leading to higher water activity in the dry pastures, which may have facilitated multiplication of Aspergillus fungus and higher AFM1 levels in milk during the July 2014 dry season.

\section{CONCLUSION}

Most of the feed from feed manufacturers analysed had AFB1 levels above the WHO/FAO and Kenyan standards [30, 31]. On the part of the government, there is a need to educate and supervise the farmers, feed traders and feed manufacturers on the importance of producing crops and feeds with low levels of, or exempt from, aflatoxin and observing good feed storage practices especially during the rainy season. In addition to providing important and novel information on aflatoxins in milk, this study shows that aflatoxin contamination is common in dairy feeds and milk and concentrations may be high. This may contribute to ill health effects in both humans and animals. Therefore, there is need for better understanding of the impacts of aflatoxins in the dairy and feed value chains and, where appropriate, interventions within these value chains to control aflatoxin contamination in animal feeds. Research can help identify the factors that 


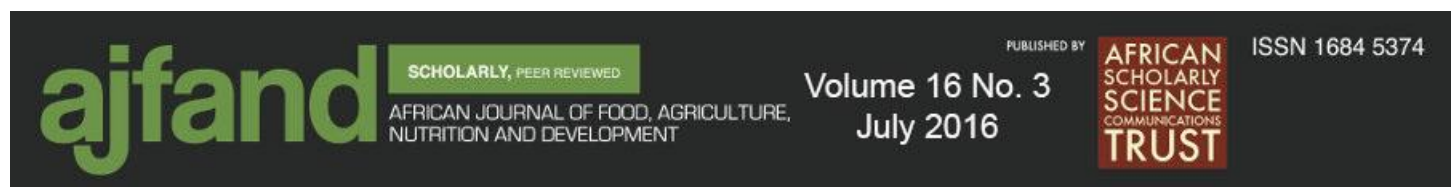

contribute to aflatoxin contamination of feeds at the feed manufacturing plants and along the dairy feed value chain.

\section{ACKNOWLEDGEMENTS}

This study was a part of the FoodAfrica Programme which is mainly financed by the Ministry for Foreign Affairs of Finland contract no. 29891501 (FoodAfrica) and the CGIAR Research Program on Agriculture for Nutrition and Health. The authors acknowledge the BecA-ILRI Hub mycotoxin laboratory for hosting the laboratory work, and Helica for providing kits at lower costs. The authors thank the participating villages and sampled households for their co-operation. 


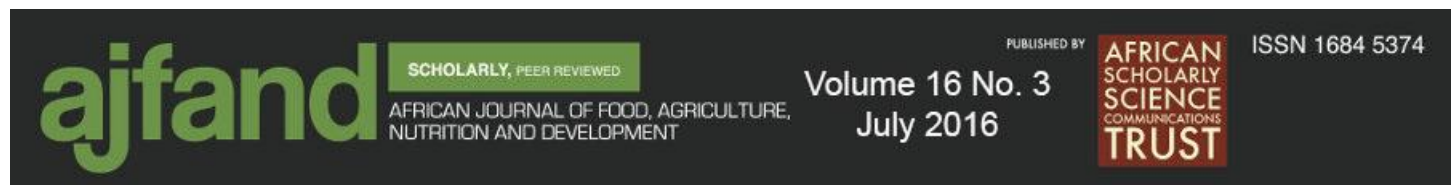

Table 1: Breed composition in study households and proportion providing dairy concentrate samples

\begin{tabular}{llccccc}
\hline County & $\begin{array}{l}\text { Agro-ecological } \\
\text { zone }\end{array}$ & $\begin{array}{c}\text { Number of cattle } \\
\text { in sampled } \\
\text { households }\end{array}$ & $\begin{array}{c}\text { Dairy } \\
\text { breeds } \\
(\%)\end{array}$ & $\begin{array}{c}\text { Cross } \\
\text { breeds } \\
(\%)\end{array}$ & $\begin{array}{c}\text { Local } \\
\text { breeds } \\
(\%)\end{array}$ & PH-C (\%) \\
\hline Kwale & Sub-humid & 409 & 2.9 & 13.0 & 84.1 & $5.4(2 / 37)$ \\
Isiolo & Semi-arid & 492 & 0.0 & 0.0 & 100.0 & $0.0(0 / 56)$ \\
Tharaka-Nithi & Humid & 153 & 32.7 & 48.4 & 19.0 & $56.3(36 / 64)$ \\
Kisii & Temperate & 193 & 40.9 & 52.3 & 6.7 & $68.8(44 / 64)$ \\
Bungoma & Temperate & 180 & 13.3 & 61.7 & 25.0 & $21.9(14 / 64)$
\end{tabular}

PH-C: proportion of households that provided dairy concentrate samples

Table 2: Cow milk production in sampled households and calf feeding practices

\begin{tabular}{llccccc}
\hline County & $\begin{array}{l}\text { Agro- } \\
\text { ecological } \\
\text { zone }\end{array}$ & $\begin{array}{c}\text { Number of } \\
\text { households } \\
\text { sampled }\end{array}$ & $\begin{array}{c}\text { Milk } \\
\text { production } \\
\text { (litres/cow/day) }\end{array}$ & $\begin{array}{c}\text { Range } \\
\text { (litres) }\end{array}$ & $\begin{array}{c}\text { Standard } \\
\text { deviation } \\
\text { (litres) }\end{array}$ & $\begin{array}{c}\text { Milk fed } \\
\text { (litres/calf/day) }\end{array}$ \\
\hline Kwale & Sub-humid & 32 & 2.35 & $0.25-29$ & 4.98 & NA \\
Isiolo & Semi-arid & 55 & 0.56 & $0.15-2.1$ & 0.43 & NA \\
Tharaka-Nithi & Humid & 62 & 3.47 & $0.3-10$ & 2.45 & 2.5 \\
Kisii & Temperate & 64 & 4.20 & $1.0-18$ & 3.07 & 3.5 \\
Bungoma & Temperate & 63 & 2.98 & $0.3-12$ & 2.30 & 1.4 \\
\hline
\end{tabular}

NA: not applicable 


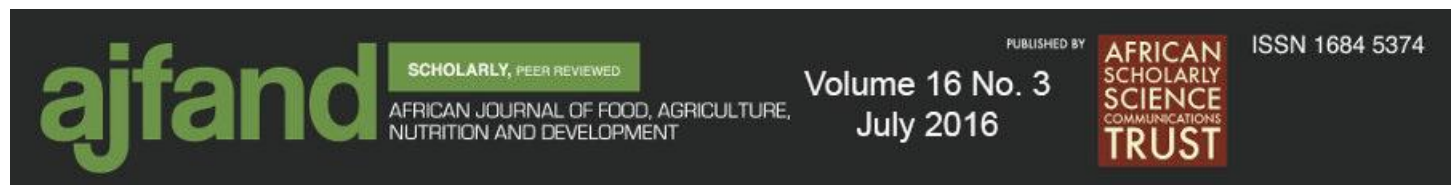

Table 3: Prevalence and levels of aflatoxin $B 1$ in feeds from different feed manufacturers encountered in the study sites

\begin{tabular}{|c|c|c|c|c|c|c|c|c|}
\hline $\begin{array}{l}\text { Feed } \\
\text { source- } \\
\text { County }\end{array}$ & $\begin{array}{l}\text { Number } \\
\text { of feed } \\
\text { samples }\end{array}$ & $\begin{array}{l}\text { Feed market- } \\
\text { County }\end{array}$ & $\begin{array}{l}\text { AEZ of } \\
\text { county where } \\
\text { feed is fed to } \\
\text { cattle }\end{array}$ & $\begin{array}{l}\text { Prevalence } \\
>5 \mathrm{ppb}(\%)\end{array}$ & Range (ppb) & $\begin{array}{l}\text { A. mean } \\
(\mathrm{ppb})\end{array}$ & $\begin{array}{l}\text { Median( } \\
\text { ppb) }\end{array}$ & $\begin{array}{c}\text { G. mean } \\
(\mathrm{ppb})\end{array}$ \\
\hline Mombasa & 7 & Kwale & Sub-humid & 28.6 & $<1-51.7$ & 9.8 & 2.9 & 2.8 \\
\hline Meru & 9 & Tharaka-Nithi & Humid & 100.0 & $14-4682$ & 875.7 & 162.3 & 175.0 \\
\hline Nakuru & 76 & Kisii, Bungoma & Temperate & 59.2 & $<1-252.9$ & 31.6 & 8.5 & 7.2 \\
\hline Bungoma & 10 & Bungoma & Temperate & 70.0 & $<1-204.7$ & 75.0 & 53.5 & 19.1 \\
\hline All & 102 & --- & --- & 61.8 & $<1-4682$ & 108.9 & 11.7 & 9.8 \\
\hline
\end{tabular}

A. mean: arithmetic mean; G. mean: geometric mean; one part per billion (ppb) is the limit of detection

Table 4: Prevalence and levels of aflatoxin B1 in feeds from feed retailers in the study sites

\begin{tabular}{lcccccc}
\hline County & $\begin{array}{c}\text { Number of } \\
\text { samples }\end{array}$ & $\begin{array}{c}\text { Prevalence } \\
>5 \mathrm{ppb}(\%)\end{array}$ & Range $(\mathrm{ppb})$ & $\begin{array}{c}\text { A. mean } \\
(\mathrm{ppb})\end{array}$ & $\begin{array}{c}\text { Median } \\
(\mathrm{ppb})\end{array}$ & $\begin{array}{c}\text { G. mean } \\
(\mathrm{ppb})\end{array}$ \\
\hline Tharaka-Nithi & 15 & 86.7 & $<1-1198$ & 115.3 & 20.3 & 19.1 \\
Kisii & 10 & 100.0 & $9-310$ & 76.8 & 48.6 & 46.6 \\
Bungoma & 6 & 83.3 & $<1-103$ & 47.1 & 52.8 & 19.7 \\
All & 31 & 90.3 & $<1-1198$ & 89.7 & 42.3 & 25.6
\end{tabular}

A. mean: arithmetic mean; G. mean: geometric mean; one part per billion (ppb) is the limit of detection 


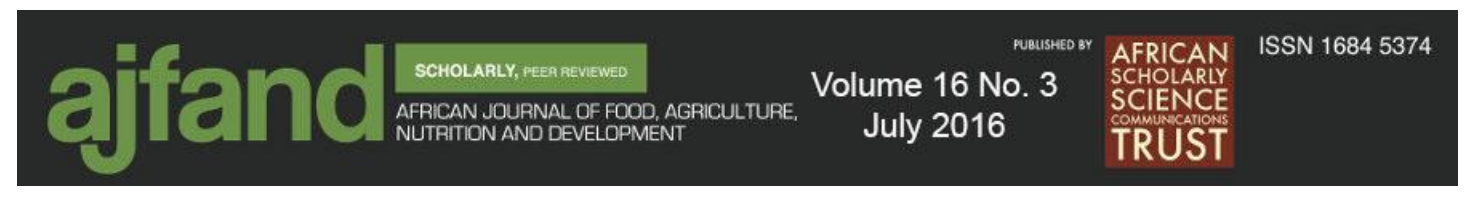

Table 5: Prevalence of aflatoxin B1 in feeds obtained from farmers in the selected counties in Kenya

\begin{tabular}{|c|c|c|c|c|c|c|c|c|c|}
\hline County & $\begin{array}{l}\text { Agro-ecological } \\
\text { zone }\end{array}$ & $\begin{array}{r}\text { Number } \\
\text { of feed } \\
\text { samples }\end{array}$ & $\begin{array}{r}\text { Prev. } \\
>1 \mathrm{ppb} \\
(\%)\end{array}$ & $\begin{array}{r}\text { Prev. } \\
>5 \mathrm{ppb} \\
(\%)\end{array}$ & $\begin{array}{r}\text { Prev. } \\
>10 \mathrm{ppb} \\
(\%)\end{array}$ & $\begin{array}{r}\text { Prev. } \\
>20 \mathrm{ppb} \\
(\%)\end{array}$ & $\begin{array}{r}\text { A. mean } \\
(\mathrm{ppb})\end{array}$ & $\begin{array}{r}\text { Median } \\
(\mathrm{ppb})\end{array}$ & $\begin{array}{r}\text { G. mean } \\
(\mathrm{ppb})\end{array}$ \\
\hline Kwale & Sub-humid & 3 & 66.7 & 33.3 & 0.0 & 0.0 & 3.5 & 4.2 & 2.3 \\
\hline Tharaka-Nithi & Humid & 72 & 90.3 & 87.5 & 79.2 & 48.6 & 348.3 & 19.4 & 24.7 \\
\hline Kisii & Temperate & 46 & 73.9 & 71.7 & 67.4 & 56.5 & 61.0 & 26.3 & 13.9 \\
\hline Bungoma & Temperate & 23 & 47.8 & 34.8 & 34.8 & 21.7 & 16.8 & 0.4 & 2,6 \\
\hline All & & 144 & 77.8 & 72.9 & 66.7 & 45.8 & 196.4 & 17.2 & 13.7 \\
\hline
\end{tabular}

Prev.: prevalence; A. mean: arithmetic mean; G. mean: geometric mean; one part per billion (ppb) is the limit of detection 


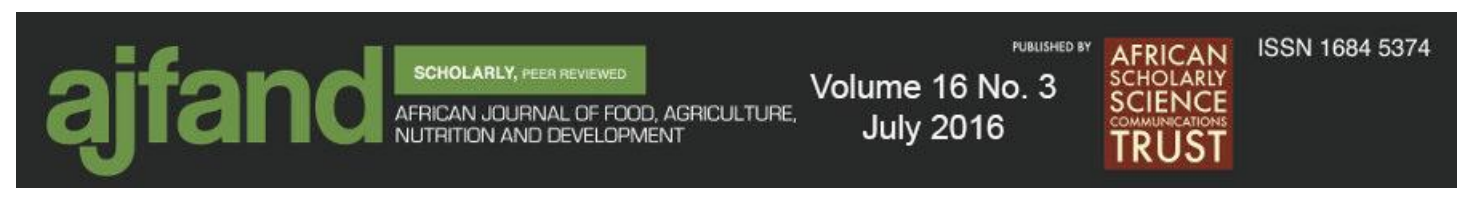

Table 6: Prevalence and levels of aflatoxin B1 in farmers feeds during dry and rainy seasons in Kenya

\begin{tabular}{|c|c|c|c|c|c|c|c|c|c|c|}
\hline County & AEZ & $\begin{array}{l}\text { Samples } \\
\text { (Season) }\end{array}$ & $\begin{array}{r}\text { Range } \\
(\mathrm{ppb})\end{array}$ & $\begin{array}{r}\text { A. mean } \\
(\mathrm{ppb})\end{array}$ & $\begin{array}{r}\text { G. mean } \\
(\mathrm{ppb})\end{array}$ & $\begin{array}{l}\text { Samples } \\
\text { (Season) }\end{array}$ & $\begin{array}{r}\text { Range } \\
(\mathrm{ppb})\end{array}$ & $\begin{array}{r}\text { A. mean } \\
(\mathrm{ppb})\end{array}$ & $\begin{array}{r}\text { G. mean } \\
(\mathrm{ppb})\end{array}$ & $\mathrm{p}$ \\
\hline Kwale & Sub-humid & 1 (dry) & 0.8 & N/A & N/A & 2 (rainy) & $4.2-5.9$ & 4.9 & 4.8 & 0.31 \\
\hline Tharaka-Nithi & Humid & 20 (dry) & $<1-28.5$ & 13.2 & 8.6 & 52 (rainy) & $<1-9661$ & 477.3 & 37.1 & 0.02 \\
\hline Kisii & Temperate & 30 (dry) & $<1-68$ & 19.9 & 5.2 & 16 (rainy) & $12-345$ & 138.1 & 88.7 & 0.03 \\
\hline Bungoma & Temperate & 11 (dry) & $<1-85$ & 22.2 & 3.8 & 12 (rainy) & $<1-81$ & 12.0 & 1.9 & 0.46 \\
\hline
\end{tabular}

AEZ: agro-ecological zone; A. mean: arithmetic mean; G. mean: geometric mean; p: two-sample Wilcoxon sign-rank test at 95\% level of confidence; one part per billion (ppb) is the limit of detection; N/A: not applicable 


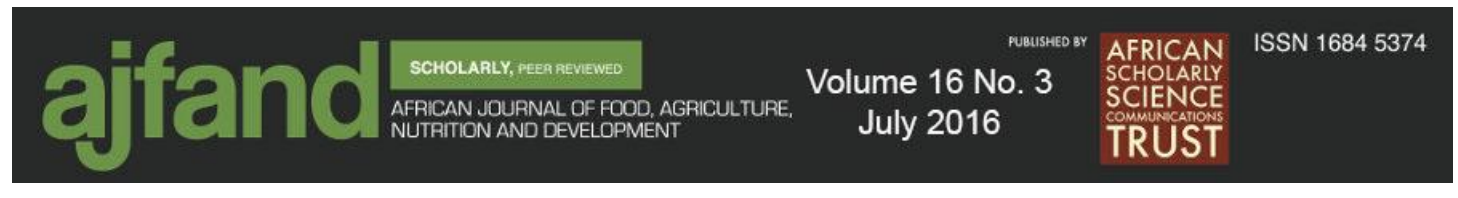

Table 7: Prevalence and levels of aflatoxin M1 in milk from farmers in Kenya

\begin{tabular}{|c|c|c|c|c|c|c|c|c|c|c|c|}
\hline County & AEZ & $\mathrm{N}$ & $\begin{array}{r}\text { Prev. } \\
>2 \text { ppt }(\%)\end{array}$ & $\begin{array}{r}\text { Prev. } \\
>5 \text { ppt }(\%)\end{array}$ & $\begin{array}{r}\text { Prev. } \\
>20 \text { ppt }(\%)\end{array}$ & $\begin{array}{r}\text { Prev. } \\
>50 \text { ppt }(\%)\end{array}$ & $\begin{array}{r}\text { Prev. } \\
>100 \text { ppt }(\%)\end{array}$ & $\begin{array}{r}\text { Range } \\
\text { (ppt) }\end{array}$ & $\begin{array}{r}\text { A. mean } \\
(p p t)\end{array}$ & $\begin{array}{r}\text { Median } \\
(\mathrm{ppt})\end{array}$ & $\begin{array}{r}\text { G. mean } \\
(p p t)\end{array}$ \\
\hline Kwale & Sub-humid & 59 & 13.6 & 11.9 & 3.4 & 3.4 & 3.4 & $<2-486$ & 13.7 & 0 & 1.5 \\
\hline Isiolo & Semi-arid & 110 & 37.3 & 27.3 & 9.1 & 3.6 & 0.9 & $<2-820$ & 14.1 & 0 & 2.5 \\
\hline Tharaka-Nithi & Humid & 126 & 65.1 & 50.8 & 36.5 & 26.2 & 10.3 & $<2-6999$ & 98.7 & 5.1 & 8.4 \\
\hline Kisii & Temperate & 111 & 31.5 & 20.7 & 16.2 & 7.2 & 4.5 & $<2-465$ & 16.2 & 0 & 2.4 \\
\hline Bungoma & Temperate & 106 & 34.9 & 31.1 & 17.0 & 5.7 & 1.9 & $<2-230$ & 12.0 & 0 & 2.8 \\
\hline All & & 512 & 39.7 & 30.7 & 18.4 & 10.4 & 4.5 & $<2-6999$ & 34.9 & 0 & 3.2 \\
\hline
\end{tabular}

AEZ: agro-ecological zone; N: number of milk samples; Prev.: prevalence (\%); A. mean: arithmetic mean; G. mean: geometric mean; two parts per trillion (ppt) is the limit of detection 


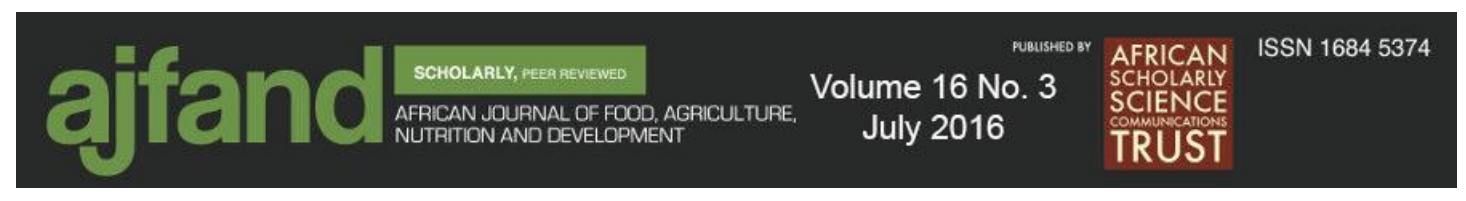

Table 8: Prevalence of aflatoxin M1 in milk during dry and rainy seasons in the study sites in Kenya

\begin{tabular}{|c|c|c|c|c|c|c|c|c|c|c|}
\hline County & AEZ & $\mathrm{N}$ (season) & $\begin{array}{r}\text { Range } \\
(\mathrm{ppt})\end{array}$ & $\begin{array}{r}\text { A. mean } \\
(p p t)\end{array}$ & $\begin{array}{r}\text { G. mean } \\
(\mathrm{ppt})\end{array}$ & $\mathrm{N}$ (season) & $\begin{array}{r}\text { Range } \\
(p p t)\end{array}$ & $\begin{array}{r}\text { A. mean } \\
(p p t)\end{array}$ & $\begin{array}{r}\text { G. mean } \\
(p p t)\end{array}$ & $\mathrm{p}$ \\
\hline Kwale & Sub-humid & 30 (dry) & $<2-256$ & 10.7 & 1.9 & 29 (rainy) & $<2-486$ & 16.7 & 1.2 & 0.02 \\
\hline Isiolo & Semi-arid & 56 (dry) & $<2-70$ & 3.6 & 1.7 & 54 (dry) & $<2-820$ & 24.9 & 3.8 & 0.02 \\
\hline Tharaka-Nithi & Humid & 64 (dry) & $<2-359$ & 32.3 & 7.9 & 62 (rainy) & $<2-6999$ & 167.6 & 9.0 & 0.75 \\
\hline Kisii & Temperate & 63 (dry) & $<2-216$ & 13.2 & 2.4 & 48 (rainy) & $<2-465$ & 20.0 & 2.4 & 0.22 \\
\hline Bungoma & Temperate & 64 (dry) & $<2-230$ & 16.2 & 4.0 & 42 (rainy) & $<2-86$ & 5.4 & 1.6 & $<0.001$ \\
\hline
\end{tabular}

AEZ: agro-ecological zone; N: number of milk samples; A. mean: arithmetic mean; G. mean: geometric mean; $\mathrm{p}=$ two-sample Wilcoxon sign-rank test at $95 \%$ confidence; two parts per trillion (ppt) is the limit of detection 


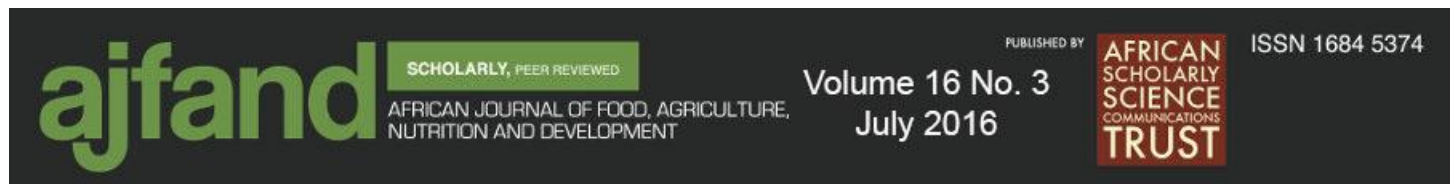

\section{REFERENCES}

1. GoK. Government of Kenya. Sessional paper of National Livestock policy. 2008.

2. FAO. Food and Agriculture Organization. Dairy Development in Kenya, by H.G. Muriuki. Rome, Italy; 2011.

3. KDB. Kenya Dairy Board. Livestock population [Internet]. Available from: www.kdb.co.ke. Accessed Apr 182015.

4. EPZA. Export Processing Zones Authority. Dairy Industry in Kenya. 2005.

5. Thorpe W, Muriuki H, Omore AO, Owango MO, and SJ Staal Development of smallholder dairying in Eastern Africa with particular reference to Kenya. Pap. Prep. UZ/RVAU/DIAS/DANIDA-ENRECA Proj. Rev. Work. 10-13 January 2000, Bronte Hotel. Harare, Zimbabwe. Nairobi, Kenya: International Livestock Research Institute; 2000.

6. SDP. Smallholder Dairy Project. The Uncertainty of Cattle Numbers in Kenya, SDP Policy Brief 10. 2006; (10): 3.

7. Behnke $\mathbf{R}$ and $\mathbf{D}$ Muthami The Contribution of Livestock to the Kenyan Economy. 2011Report No.: 3 - 11.

8. Theron HE and BE Mostert Production and breeding performance of South African dairy herds. South African J. Anim. Sci. 2009; 39(Supplement 1): 206210 .

9. USDA. Milk production. USDA Publ. 2015.

10. IARC. International Agency for Research on Cancer. IARC Monographs on the Evaluation of Carcinogenic Risks to Humans. Some Naturally Occurring Substances: Food Items and Constituents, Heterocyclic Aromatic Amines and Mycotoxins. 56th ed. Lyon, France: IARC Press; 1993.

11. Probst $\mathbf{C}$, Njapau $\mathbf{H}$ and PJ Cotty Outbreak of an acute aflatoxicosis in Kenya in 2004: identification of the causal agent. Appl Env. Microbiol University of Arizona, USDA-ARS, Department of Plant Sciences, Tucson, AZ 85721, USA.; 2007; 73: 2762-2764.

12. Lewis L, Onsongo M, Njapau H, Schurz-Rogers H, Luber G, Kieszak S, Nyamongo J, Backer L, Dahiye AM, Misore A, DeCock K, Rubin C and KAI Group Aflatoxin contamination of commercial maize products during an outbreak of acute aflatoxicosis in eastern and central Kenya. Env. Heal. Perspect National Center for Environmental Health, Centers for Disease Control and Prevention, Chamblee, Georgia 30341, USA.1wb6@cdc.gov; 2005; 113: 1763-1767. 


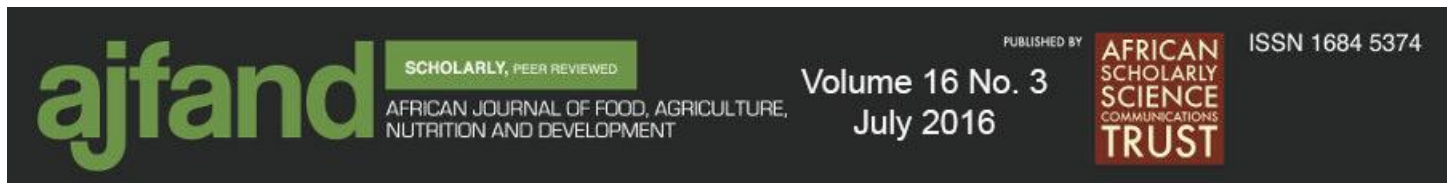

13. Azziz-Baumgartner E, Lindblade K, Gieseker K, Rogers HS, Kieszak S, Njapau H, Schleicher R, McCoy LF, Misore A, DeCock K, Rubin C, Slutsker L and AI Group Case-control study of an acute aflatoxicosis outbreak, Kenya, 2004. Env. Heal. Perspect National Center for Environmental Health, Centers for Disease Control and Prevention, Atlanta, Georgia 30341-3717, USA. eha9@cdc.gov; 2005; 113: 1779-1783.

14. Muture BN and G Ogana Aflatoxin levels in maize and maize products during the 2004 food poisoning outbreak in Eastern Province of Kenya. East Afr Med J National Public Health Laboratory Services, P.O. Box 20750, Nairobi, Kenya.; 2005; 82: 275-279.

15. Wagacha JM and JW Muthomi Mycotoxin problem in Africa: current status, implications to food safety and health and possible management strategies. Int. J. Food Microbiol. 2008; 124(1): 1-12.

16. Daniel JH, Lewis LW, Redwood YA, Kieszak S, Breiman RF, Flanders WD, Bell C, Mwihia J, Ogana G, Likimani S, Straetemans M and MA McGeehin Comprehensive assessment of maize aflatoxin levels in Eastern Kenya, 20052007. Env. Heal. Perspect Centers for Disease Control and Prevention, Atlanta, Georgia 30341, USA. bez2@cdc.gov; 2011; 119: 1794-1799.

17. Muthomi JW, Njenga LN, Gathumbi JK and GN Cheminingâ The Occurrence of Aflatoxins in Maize and Distribution of Mycotoxin-Producing Fungi in Eastern Kenya. Plant Pathol. J. 2009; 8(3): 113-119.

18. Sultana $\mathbf{N}$ and NQ Hanif Mycotoxin contamination in cattle feed and feed ingredients. Pak. Vet. J. 2009; 29(4): 211-213.

19. Guthrie LD and DM Bedell Effects of aflatoxin in corn on production and reproduction in dairy cattle. Proc. Annu. Meet. U. S. Anim. Health Assoc. 1979; (83): 202-204.

20. Carlson MP and R Smith Aflatoxin M1 in Milk. Agriculture 2002; 3.

21. Yard EE, Daniel JH, Lewis LS, Rybak ME, Paliakov EM, Kim AA, Montgomery JM, Bunnell R, Abudo MU, Akhwale W, Breiman RF and SK Sharif Human aflatoxin exposure in Kenya, 2007: a cross-sectional study. Food Addit Contam Part A Chem Anal Control Expo Risk Assess Centers for Disease Control and Prevention, National Center for Environmental Health, Chamblee, GA, USA. eyard@cdc.gov; 2013; 30: 1322-1331.

22. Mutiga SK, Were V, Hoffmann V, Harvey JW, Milgroom MG and RJ Nelson Extent and drivers of mycotoxin contamination: inferences from a survey of kenyan maize mills. Phytopathology 2014; 104(11): 1221-1231. 


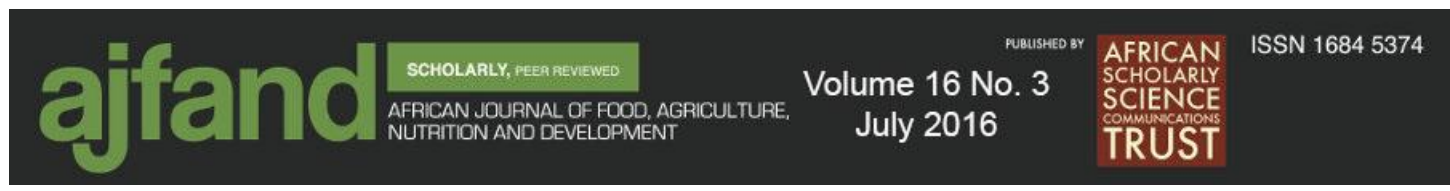

23. Kang'ethe EK, M'Ibui GM, Randolph TF and AK Langat Prevalence of aflatoxin $\mathrm{m} 1$ and $\mathrm{b} 1$ in milk and animal feeds from urban smallholder dairy production in Dagoretti Division, Nairobi, Kenya. East Afr. Med. J. 2007; 84(11): S83-S86.

24. Kang'ethe EK and AK Lang'a Aflatoxin B1 and M1 contamination of animal feeds and milk from urban centers in Kenya. Afr. Health Sci. 2009; 9(4): 218-226.

25. Okoth S, Nyongesa B, Ayugi V, Kang'ethe E, Korhonen H and V Joutsjoki Toxigenic potential of Aspergillus species occurring on maize kernels from two agro-ecological zones in Kenya. Toxins (Basel) School of Biological Sciences, University of Nairobi P. O. Box 30197-00100 Nairobi, Kenya. dorisokoth@yahoo.com; 2012; 4: 991-1007.

26. IIASA/FAO. Global Agro-Ecological Zones (GAEZ). 2012.

27. Dohoo IR, Martin SW and H Stryhn Methods in epidemiologic research. Charlottetown: VER Inc.; 2012; 40-42.

28. Gizachew D, Szonyi B, Tegegne A, Hanson J and D Grace Aflatoxin contamination of milk and dairy feeds in the Greater Addis Ababa milk shed, Ethiopia. Food Control 2016; 59: 773-779.

29. Probst C, Callicott KA and PJ Cotty Deadly strains of Kenyan Aspergillus are distinct from other aflatoxin producers. Eur. J. Plant Pathol. 2012; 132(3): 419429.

30. FAO/WHO. Food and Agriculture Organization/World Health Organization. Standards Programme. Codex Aliment. Comm. Alinom 91/12 1990.

31. KEBS. Kenya Beaureau of Standards. Dairy cattle feed supplements - Dairy Meal KS 62:2009. 2009. 